\title{
Pittosporum leroyanum
}

\author{
Assessment by: Gemmill, C. et al.
}

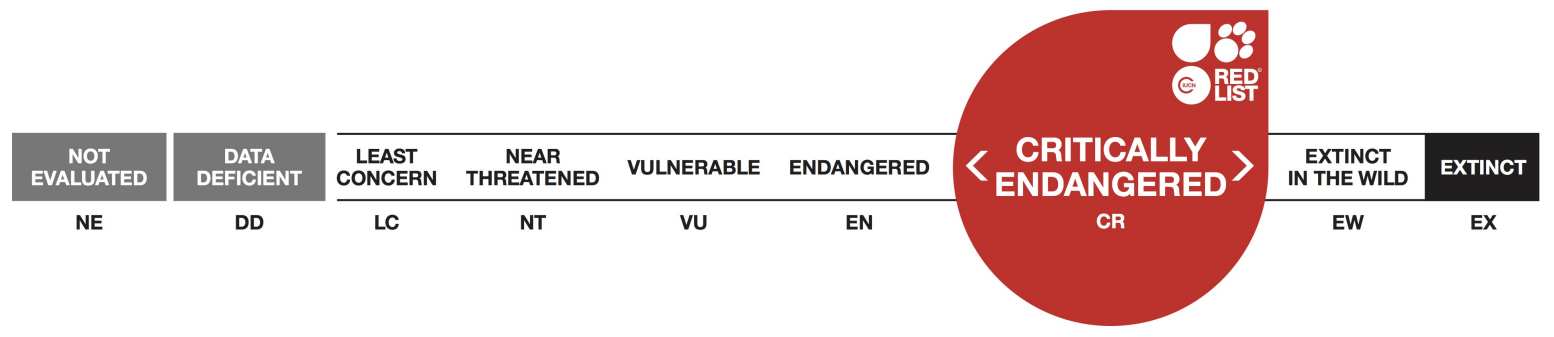

View on www.iucnredlist.org

Short citation: Gemmill, C. et al. 2017. Pittosporum leroyanum. The IUCN Red List of Threatened Species 2017: e.T82947753A82951832. http://dx.doi.org/10.2305/IUCN.UK.20173.RLTS.T82947753A82951832.en [see full citation at end]

Copyright: (C 2017 International Union for Conservation of Nature and Natural Resources Reproduction of this publication for educational or other non-commercial purposes is authorized without prior written permission from the copyright holder provided the source is fully acknowledged.

Reproduction of this publication for resale, reposting or other commercial purposes is prohibited without prior written permission from the copyright holder. For further details see Terms of Use.

The IUCN Red List of Threatened Species ${ }^{T M}$ is produced and managed by the IUCN Global Species Programme, the IUCN Species Survival Commission (SSC) and The IUCN Red List Partnership. The IUCN Red List Partners are: Arizona State University; BirdLife International; Botanic Gardens Conservation International; Conservation International; NatureServe; Royal Botanic Gardens, Kew; Sapienza University of Rome; Texas A\&M University; and Zoological Society of London.

If you see any errors or have any questions or suggestions on what is shown in this document, please provide us with feedback so that we can correct or extend the information provided. 


\section{Taxonomy}

\begin{tabular}{|c|c|c|c|c|}
\hline Kingdom & Phylum & Class & Order & Family \\
\hline Plantae & Tracheophyta & Magnoliopsida & Rosales & Pittosporaceae \\
\hline
\end{tabular}

Taxon Name: Pittosporum leroyanum Tirel \& Veillon

\section{Taxonomic Source(s):}

Tirel, Ch. and Veillon, J.-M. 2002. Flore de la Nouvelle-Calédonie, tome 24. Pittosporaceae. Museum d'Histoire Naturelle, Paris.

\section{Assessment Information}

Red List Category \& Criteria: Critically Endangered (Possibly Extinct) D ver 3.1

Year Published:

Date Assessed:
2017

July 24, 2015

\section{Justification:}

A rare endemic shrub of New Caledonia, Pittosporum leroyanum is known only from one locality: Gadji forest on île des Pins. Pittosporum leroyanum has been recollected only once in 1980 in undergrowth dense forest containing some elements of slerophyllous forest on madreporic substrate at low altitude. Since this collection, P. leroyanum has never been seen again despite field survey efforts. On the basis of this single collection and difficulties to locate the population again, population size is estimated to be fewer than 50 mature individuals. Using criterion D, P. leroyanum qualifies as Critically Endangered (Possibly Extinct) (CR PE) D.

Date last seen: 1980

\section{Geographic Range}

\section{Range Description:}

A rare endemic shrub of New Caledonia, Pittosporum leroyanum is known only from one locality at Gadji forest on île des Pins.

\section{Country Occurrence:}

Native: New Caledonia 


\section{Distribution Map}

\section{Pittosporum leroyanum}
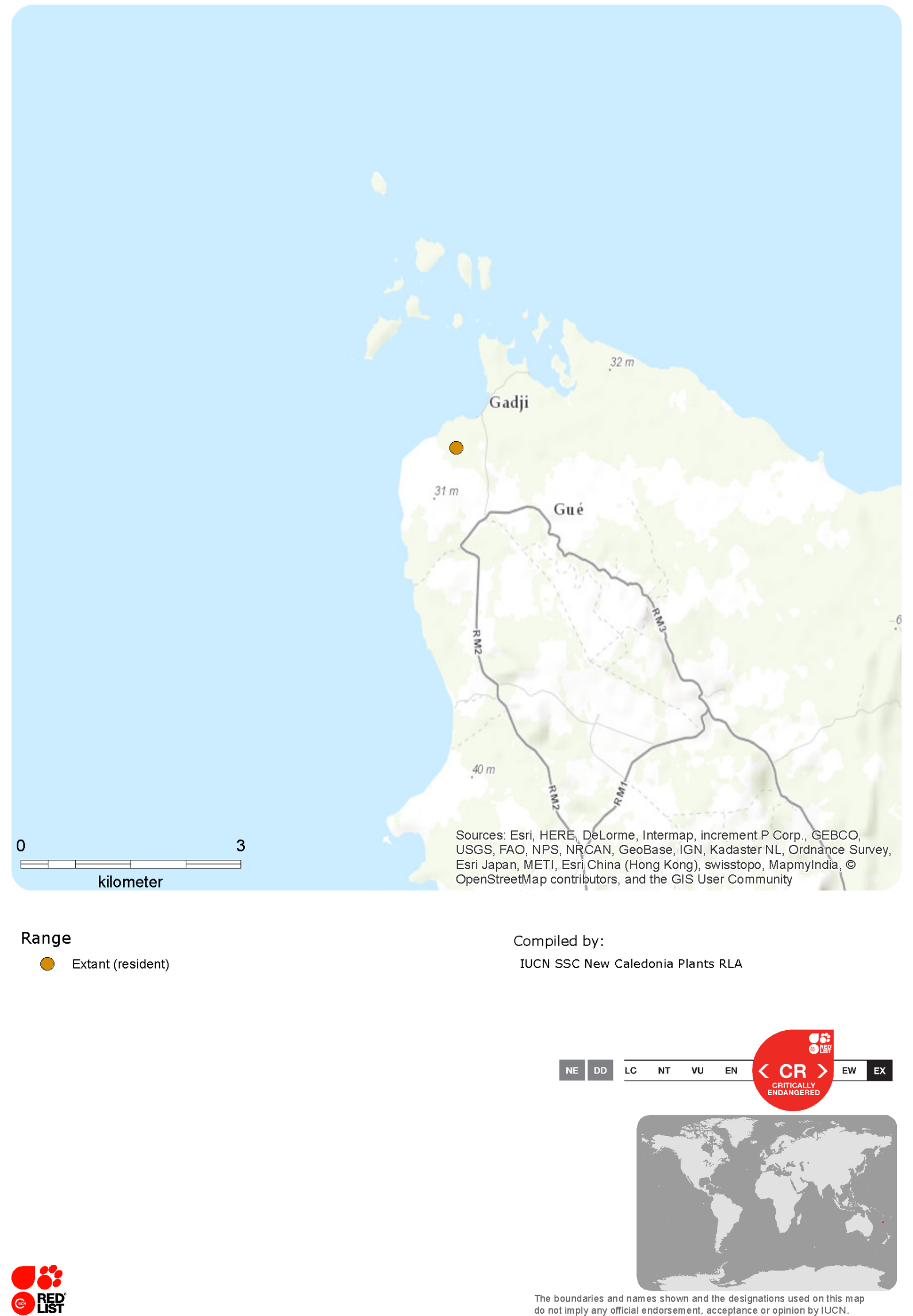


\section{Population}

Since 1980 , Pittosporum leroyanum has never been seen again in spite of field surveys efforts, total population size is estimated to be fewer than 50 individuals.

Current Population Trend: Unknown

\section{Habitat and Ecology (see Appendix for additional information)}

Pittosporum leroyanum has been recollected only once in 1980 in the undergrowth of dense forest containing some elements of slerophyllous forest on madreporic substrate at low altitude.

Systems: Terrestrial

\section{Threats}

This rare species is declared missing without identifying the threat in question.

\section{Conservation Actions (see Appendix for additional information)}

Pittosporum leroyanum is not protected by any legislation nor does it occur in any protected areas. Field surveys on île des Pins are required to confirm its extinction.

\section{Credits}

Assessor(s): $\quad$ Gemmill, C., Veillon, J.-M., Amice, R., Cazé, H., Dumontet, V., Fleurot, D., Garnier, D., Gâteblé, G., Letocart, I., Letocart, D., Maggia, L. \& Pain, A.

Reviewer(s): $\quad$ Tanguy, V.

Facilitators(s) and Chanfreau, S.

Compiler(s): 


\section{Bibliography}

Bouchet, P., Jaffré, T. and Veillon J.-M. 1995. Plant extinction in New Caledonia: protection of sclerophyll forest urgently needed. Biodiversity \& Conservation 4: 415-428.

Endemia.nc. 2016. Faune et Flore de Nouvelle-Calédonie. Available at: http://www.endemia.nc.

IUCN. 2017. The IUCN Red List of Threatened Species. Version 2017-3. Available at: www.iucnredlist.org. (Accessed: 7 December 2017).

Tirel, Ch. and Veillon, J.-M. 2002. Flore de la Nouvelle-Calédonie, tome 24. Pittosporaceae. Museum d'Histoire Naturelle, Paris.

\section{Citation}

Gemmill, C., Veillon, J.-M., Amice, R., Cazé, H., Dumontet, V., Fleurot, D., Garnier, D., Gâteblé, G., Letocart, I., Letocart, D., Maggia, L. \& Pain, A. 2017. Pittosporum leroyanum. The IUCN Red List of Threatened Species 2017: e.T82947753A82951832. http://dx.doi.org/10.2305/IUCN.UK.20173.RLTS.T82947753A82951832.en

\section{Disclaimer}

To make use of this information, please check the Terms of Use.

\section{External Resources}

For Images and External Links to Additional Information, please see the Red List website. 


\section{Appendix}

\section{Habitats}

(http://www.iucnredlist.org/technical-documents/classification-schemes)

\begin{tabular}{|c|c|c|c|}
\hline Habitat & Season & Suitability & $\begin{array}{l}\text { Major } \\
\text { Importance? }\end{array}$ \\
\hline 1. Forest -> 1.6. Forest - Subtropical/Tropical Moist Lowland & - & Suitable & - \\
\hline
\end{tabular}

\section{Conservation Actions in Place}

(http://www.iucnredlist.org/technical-documents/classification-schemes)

\begin{tabular}{|l|}
\hline Conservation Actions in Place \\
\hline In-Place Land/Water Protection and Management \\
\hline Occur in at least one PA: No \\
\hline Invasive species control or prevention: No \\
\hline In-Place Species Management \\
\hline Successfully reintroduced or introduced beningly: No \\
\hline Subject to ex-situ conservation: No \\
\hline
\end{tabular}

\section{Research Needed}

(http://www.iucnredlist.org/technical-documents/classification-schemes)

\section{Research Needed}

1. Research -> 1.1. Taxonomy

1. Research $->1.2$. Population size, distribution $\&$ trends

\section{Additional Data Fields}

\begin{tabular}{|l|}
\hline Distribution \\
\hline Estimated area of occupancy $(\mathrm{AOO})\left(\mathrm{km}^{2}\right): 4$ \\
\hline Continuing decline in area of occupancy (AOO): Unknown \\
\hline Extreme fluctuations in area of occupancy (AOO): No \\
\hline Estimated extent of occurrence (EOO) ( $\left.\mathrm{km}^{2}\right): 4$ \\
\hline Continuing decline in extent of occurrence (EOO): Unknown \\
\hline Extreme fluctuations in extent of occurrence (EOO): No \\
\hline Continuing decline in number of locations: Unknown \\
\hline
\end{tabular}




\section{Distribution}

Extreme fluctuations in the number of locations: No

Lower elevation limit $(m): 5$

Upper elevation limit (m): 20

\section{Population}

Number of mature individuals: $1-49$

Continuing decline of mature individuals: Unknown

Extreme fluctuations: No

Population severely fragmented: No

No. of subpopulations: 1

Extreme fluctuations in subpopulations: No

Habitats and Ecology

Continuing decline in area, extent and/or quality of habitat: Unknown

Generation Length (years): 0 


\section{The IUCN Red List Partnership}

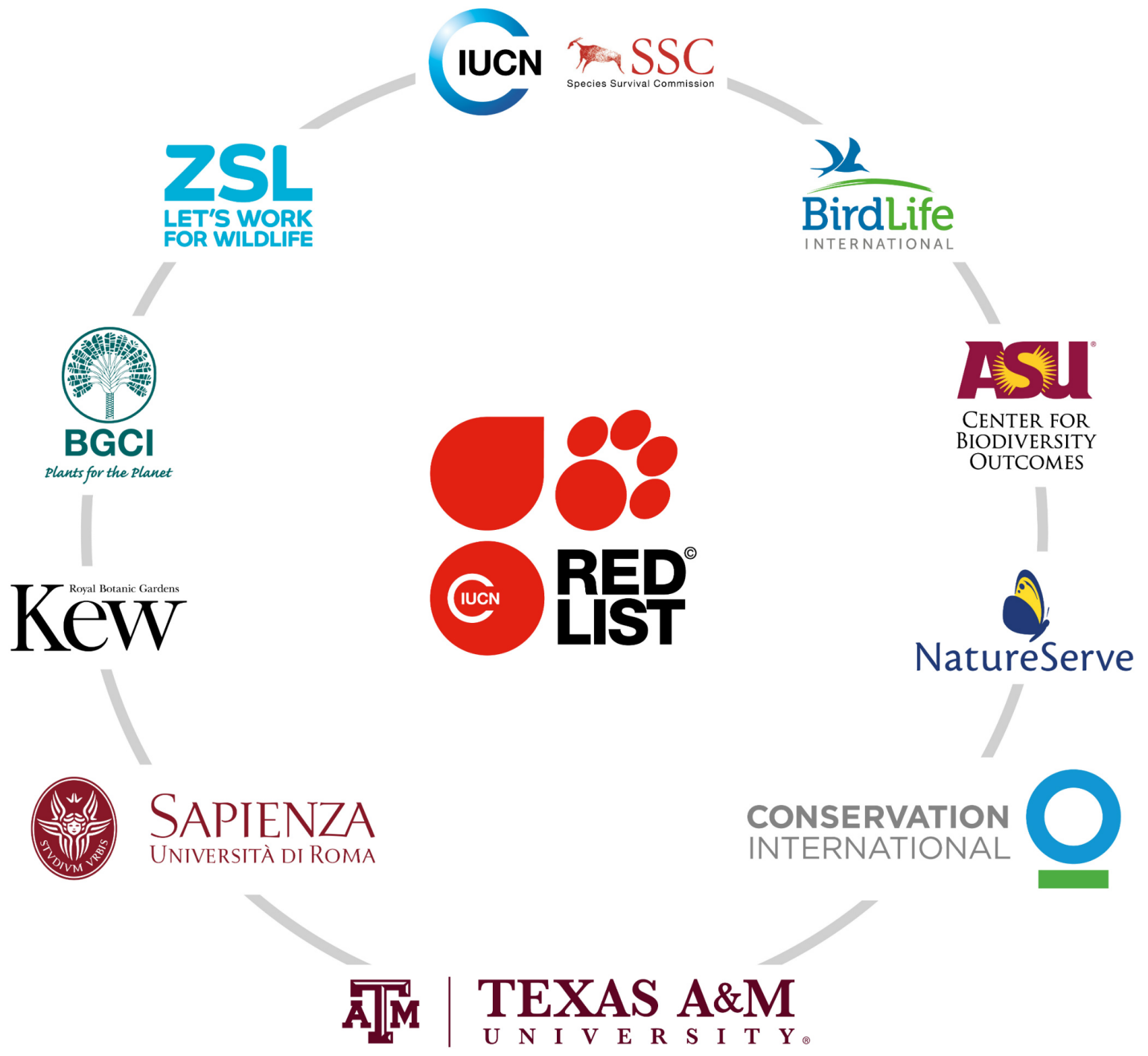

The IUCN Red List of Threatened Species ${ }^{\mathrm{TM}}$ is produced and managed by the IUCN Global Species Programme, the IUCN Species Survival Commission (SSC) and The IUCN Red List Partnership.

The IUCN Red List Partners are: Arizona State University; BirdLife International; Botanic Gardens Conservation International; Conservation International; NatureServe; Royal Botanic Gardens, Kew; Sapienza University of Rome; Texas A\&M University; and Zoological Society of London. 